\title{
Post-coring entrapment of modern air in some shallow ice cores collected near the firn-ice transition: evidence from CFC-12 measurements in Antarctic firn air and ice cores
}

\author{
M. Aydin ${ }^{1}$, S. A. Montzka ${ }^{2}$, M. O. Battle ${ }^{3}$, M. B. Williams ${ }^{6}$, W. J. De Bruyn ${ }^{4}$, J. H. Butler ${ }^{2}$, K. R. Verhulst ${ }^{1}$,

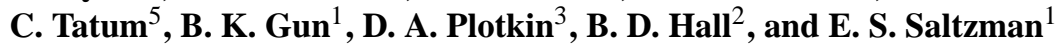 \\ ${ }^{1}$ Department of Earth System Science, University of California, Irvine, California, USA \\ ${ }^{2}$ Earth System Research Laboratories - Global Monitoring Division, National Oceanic and Atmospheric Administration, \\ Boulder, Colorado, USA \\ ${ }^{3}$ Department of Physics and Astronomy, Bowdoin College, Brunswick, Maine, USA \\ ${ }^{4}$ Schmid College of Science, Chapman University, Orange, California, USA \\ ${ }^{5}$ Rosenstiel School of Marine and Atmospheric Science, University of Miami, Miami, Florida, USA \\ ${ }^{6}$ ICF International, San Francisco, California, USA
}

Received: 5 January 2010 - Published in Atmos. Chem. Phys. Discuss.: 21 January 2010

Revised: 22 April 2010 - Accepted: 22 May 2010 - Published: 9 June 2010

\begin{abstract}
In this study, we report measurements of CFC$12\left(\mathrm{CCl}_{2} \mathrm{~F}_{2}\right)$ in firn air and in air extracted from shallow ice cores from three Antarctic sites. The firn air data are consistent with the known atmospheric history of CFC-12. In contrast, some of the ice core samples collected near the firn-ice transition exhibit anomalously high CFC-12 levels. Together, the ice core and firn air data provide evidence for the presence of modern air entrapped in the shallow ice core samples that likely contained open pores at the time of collection. We propose that this is due to closure of the open pores after drilling, entrapping modern air and resulting in elevated CFC-12 mixing ratios. Our results reveal that open porosity can exist below the maximum depth at which firn air samples can be collected, particularly at sites with lower accumulation rates. CFC-12 measurements demonstrate that post-drilling closure of open pores can lead to a change in the composition of bubble air in shallow ice cores through purely physical processes. The results have implications for investigations involving trace gas composition of bubbles in shallow ice cores collected near the firn-ice transition.
\end{abstract}

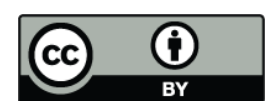

Correspondence to: M. Aydin (maydin@uci.edu)

\section{Introduction}

The air in polar firn and ice cores is a unique archive of the ancient atmosphere. Extraction and analysis of this air has enabled reconstruction of paleo-atmospheric records of carbon dioxide (Petit et al., 1999; Lüthi et al., 2008), methane (Brook et al., 1996), and nitrous oxide (Sowers et al., 2003), which have been validated by establishing consistency between gas records from multiple ice core sites. Similarly, contemporaneous data from different sites have been used to demonstrate continuity between the instrumental time series measurements, and firn air and ice core gas records (Battle et al., 1996; Etheridge et al., 1996).

Firn is the layer of perennial snow that sits atop the underlying impermeable ice of persistent ice sheets. Firn can vary in thickness from tens of meters to over a hundred meters. It is porous and allows the air within to mix with the overlying atmosphere. The diffusivity in firn decreases with depth as the snow densifies, causing the age of interstitial air to increase with depth. The decrease in permeability is most rapid near the bottom of the firn, in the lock-in zone, where the bubble close-off process starts and the permeability drops to near zero. At some depth below the lock-in zone, the transition of firn to impermeable ice is complete and all air is occluded in bubbles (Battle et al., 1996; Schwander et al., 1993; Severinghaus and Battle, 2006). This full close-off

Published by Copernicus Publications on behalf of the European Geosciences Union. 
depth can be estimated from direct measurements of closed porosity (Martinerie et al., 1992; Schwander et al., 1989).

Various physical processes can alter gas compositions and isotopic ratios of air in the firn prior to and during bubble close-off (Bender, 2002; Craig et al., 1988; Schwander, 1989; Severinghaus et al., 2001; Severinghaus and Battle, 2006). Once entrapped in bubbles, the abundance of a particular gas in the ice core air may yet change through processes that occur in situ or during storage following the retrieval of the cores (Anklin et al., 1997; Bender, 2002; Bender et al., 1995; Delmas, 1993; Haan and Raynaud, 1998; IkedaFukazawa et al., 2005). Understanding the impact of such processes is important because they may ultimately influence the interpretation of ice core gas records.

Recently, firn air and ice core studies have been used to examine the atmospheric variability of less abundant trace gases such as methyl chloride, methyl bromide, and carbonyl sulfide (Aydin et al., 2008; Butler et al., 1999; Montzka et al., 2004; Saito et al., 2007; Saltzman et al., 2008; Sturges et al., 2001a, b; Trudinger et al., 2004; Williams et al., 2007). These measurements, which can potentially be extended to a range of low-level trace gases, allow for examination of the natural variability in atmospheric levels of these compounds as well as the influence of human activities on the trace gas composition of the atmosphere. Such gases are typically present at parts-per-trillion (ppt) levels in modern air. As a result, they are very sensitive to contamination during sampling, storage, and analysis.

One of the trace gases we routinely measure during ice core analysis is CFC-12 $\left(\mathrm{CCl}_{2} \mathrm{~F}_{2}\right)$, with the primary purpose of identifying vacuum leaks in the extraction and analytical systems. CFC-12 is a synthetic chlorofluorocarbon manufactured during the 20th century for use as a refrigerant and an aerosol spray propellant. Its atmospheric history is well established with agreement between instrumental time series measurements beginning in 1978 and industry-reported production and emission data (Walker et al., 2000), the distribution of dissolved CFC-12 in the oceans (e.g. Weiss et al., 1985), and firn air measurements (Butler et al., 1999; Sturrock et al., 2002). Its atmospheric history (ftp://ftp.cmdl.noaa.gov/hats/firnair/) indicates that the CFC12 mixing ratio in the atmosphere was less than $1 \mathrm{ppt}$ before the 1940's. In this study, we focus on the compositional integrity of the air bubbles trapped in shallow ice cores, using CFC-12 measurements as a tool to identify post-coring entrapment of modern air.

\section{Samples and site characteristics}

Ice core samples used in this study are from three Antarctic sites: 1) SPRESSO core drilled about $8 \mathrm{~km}$ away from South Pole $\left(89.93^{\circ} \mathrm{S}, 144.39^{\circ} \mathrm{W}, 2800 \mathrm{~m}\right.$ a.s.1.), 2) WAIS-D 05A core drilled at the West Antarctic Ice Sheet Divide $\left(79.46^{\circ} \mathrm{S}\right.$, $112.13^{\circ} \mathrm{W}, 1759 \mathrm{~m}$ a.s.l.), and 3) SDM-C core drilled at Siple
Dome $\left(81.65^{\circ} \mathrm{S}, 148.81^{\circ} \mathrm{W}, 620 \mathrm{~m}\right.$ a.s.1.). All three cores were dry-drilled, SPRESSO to a depth of $291 \mathrm{~m}$ as part of the International Trans-Antarctic Scientific Expedition (ITASE) program (http://www2.umaine.edu/itase/) in 2002, WAIS-D 05A to a depth of $298 \mathrm{~m}$ in 2005 (http://www.waisdivide.unh. edu/), and the SDM-C core to a depth of $92 \mathrm{~m}$ in 1995 as part of the West Antarctic Ice Sheet Program.

The physical environmental characteristics vary considerably among the sites (Table 1). The mean annual temperature is $-31.0^{\circ} \mathrm{C}$ at WAIS divide, $-25.4^{\circ} \mathrm{C}$ at Siple Dome, and $-51.0^{\circ} \mathrm{C}$ at South Pole. The accumulation rate for the WAIS-D 05A core is $22.2 \mathrm{~cm} / \mathrm{y}$ based on a combination of ion chemistry data from the top $70 \mathrm{~m}$ and continuous electrical conductivity and di-electric property (ECM/DEP) measurements between $70 \mathrm{~m}$ and $298 \mathrm{~m}$ (Mischler et al., 2009), and the accumulation rate for SDM-C is $11.4 \mathrm{~cm} / \mathrm{y}$ based on visual stratigraphy (Richard B. Alley, http://nsidc.org/data/ waiscores). The mean accumulation rate over the top $207 \mathrm{~m}$ of the SPRESSO core is $8.3 \mathrm{~cm} / \mathrm{y}$ (A. Gow, personal communication, 2006) based on visual stratigraphy.

The WAIS-D firn air samples were collected from two shallow holes drilled adjacent to WAIS-D 05A in 2005 and named 05C and 05E. The Siple Dome firn study was conducted in 1996, one year after the collection of the SDM-C core at the Siple Dome deep drilling site. South Pole data are from two firn holes drilled near the geographic pole: one in 1995 (SPO'95) and the other in 2001 (SPO'01). Siple Dome and the South Pole firn air samples were analyzed by the halocarbons group at NOAA/ESRL Global Monitoring Division. There are two sets of CFC-12 data from WAIS-D. These data are obtained from measurements on two separate sets of flasks filled sequentially from the same two firn holes and analyzed in laboratories at NOAA/ESRL and at UCI.

\section{Experimental}

\subsection{Ice core analysis (UCI)}

All ice core CFC-12 analyses were performed in the laboratories at UCI. The Siple Dome measurements were completed using "dry-extraction" of ice core air and subsequent analysis in a GC-MS system. The specifics of the extraction and analytical procedures for Siple Dome samples are previously published (Aydin et al., 2002). The WAIS-D and SPRESSO samples were extracted and analyzed using an updated procedure described in detail by Aydin et al. (2007). These techniques were previously used to measure $\mathrm{CH}_{3} \mathrm{Cl}$, $\mathrm{CH}_{3} \mathrm{Br}$, and $\mathrm{COS}$ (Williams et al., 2007; Aydin et al., 2008; Saltzman et al., 2008) and were applied unchanged during the analysis of WAIS-D and SPRESSO samples. Since the validity of our results hinges on the integrity of our methodology, we present a summary in the rest of this section. These methods are currently used in ice core analysis at UCI and apply to WAIS-D and SPRESSO samples. 
Table 1. Site characteristics for the three locations used in this study. Full close-off depth as calculated with Eq. (1).

\begin{tabular}{llll}
\hline & South Pole (SPRESSO) & WAIS Divide (WAIS-D) & Siple Dome (SDM-C) \\
\hline Latitude - Longitude & $89.93^{\circ} \mathrm{S}-144.39^{\circ} \mathrm{W}$ & $79.46^{\circ} \mathrm{S}-112.13^{\circ} \mathrm{W}$ & $81.65^{\circ} \mathrm{S}-148.81^{\circ} \mathrm{W}$ \\
Elevation (a.s.l.) & $2800 \mathrm{~m}$ & $1759 \mathrm{~m}$ & $620 \mathrm{~m}$ \\
Mean annual temperature & $-51.0^{\circ} \mathrm{C}$ & $-31.0^{\circ} \mathrm{C}$ & $-25.4^{\circ} \mathrm{C}$ \\
Accumulation Rate (Ice equivalent) & $8.3 \mathrm{~cm} / \mathrm{y}$ & $22.2 \mathrm{~cm} / \mathrm{y}$ & $11.4 \mathrm{~cm} / \mathrm{y}$ \\
Deepest firn air sample & $121.3 \mathrm{~m}$ & $76.5 \mathrm{~m}$ & $56.5 \mathrm{~m}$ \\
Empirical estimate of full close-off depth & $117.7 \mathrm{~m}$ & $80.1 \mathrm{~m}$ & $53.4 \mathrm{~m}$ \\
Date drilled & 2002 & 2005 & 1995 \\
\hline
\end{tabular}

In dry-extraction, air is mechanically liberated from the ice core without melting the ice. The extraction chamber is a stainless steel tube $\left(20 \mathrm{~cm}\right.$ long, $6000 \mathrm{~cm}^{3}$ volume) sealed on both ends with conflat flanges. Welded inside is a flat, stainless steel grater that acts as a cutting surface. There is a stainless steel bellows valve welded on to one of the side flanges for pumping and gas extraction. The size of the ice samples were typically $\sim 15 \mathrm{~cm}$ long $(10-18 \mathrm{~cm}$ range), from gas sample specific cuts to minimize inclusion of the outer layer of the core that contacts the drill during recovery. The outer $4-6 \mathrm{~mm}$ of each ice sample is shaved off with a clean stainless scalpel immediately before it is loaded in the extraction chamber. This is primarily to avoid potential contamination from prior handling of the ice and to eliminate the micro-cracks that may exist close to the drilling surface. Any part of the sample that includes visible cracks is also shaved off at this stage. At the start of the extraction, the chamber is placed on a cradle built inside a chest freezer. The cradle is connected to a motor with steel shafts that run through the side walls of the freezer and is put into linear oscillatory motion $(15 \mathrm{~cm}$ throw at $1 \mathrm{~Hz})$ to shred the sample. The freezer temperature is maintained at $-50^{\circ} \mathrm{C}$ during extraction. After 15 min of shredding, the motor is stopped and the extraction chamber is connected to a vacuum line via a flexible stainless steel tube. The sample in the chamber is transferred into a $70 \mathrm{~cm}$ long, 1/4" OD stainless steel tube, which is cooled on one end to $4 \mathrm{~K}$, using liquid $\mathrm{He}$. The average amount of the air extracted from the WAIS-D, Siple Dome, and SPRESSO samples were $38 \pm 9 \mathrm{ml} \mathrm{STP}, 42 \pm 9 \mathrm{ml} \mathrm{STP}$, and $31 \pm 7 \mathrm{ml} \mathrm{STP}$ $( \pm 1 \sigma)$, respectively.

A pre- and a post-shred $\mathrm{N}_{2}$ blank is analyzed for each sample to test the vacuum integrity of the extraction chamber and the cleanliness of each ice core sample. Clean $\mathrm{N}_{2}$ gas is introduced into the extraction chamber after the sample is loaded and isolated for the same amount of time it takes to shred a sample ( $15 \mathrm{~min})$. The size of the $\mathrm{N}_{2}$ introduced into the cans is comparable to a typical ice core sample (30-50 $\mathrm{ml} \mathrm{STP).}$ All equipment and procedures during both the pre- and postshred blanks are the same as the sample runs except the cradle is not put into motion to avoid shredding the ice core sample as some ice remains intact inside the can even after the shredding.
The samples are analyzed for an array of trace gases using gas chromatography with mass spectrometric detection (GCMS). The GC oven (6890 - Agilent corp.) is fitted with the cryogenic cooling option and a $60 \mathrm{~m}$ long non-polar DB-1 column that is operated in constant flow mode at $1 \mathrm{ml} / \mathrm{min}$. A chromatography run starts with $3 \mathrm{~min}$ of isothermal separation at $-50^{\circ} \mathrm{C}$, followed by warming first at a rate of $10^{\circ} \mathrm{C} / \mathrm{min}$ to $-40^{\circ} \mathrm{C}$, and then at $30^{\circ} \mathrm{C} / \mathrm{min}$ to $150^{\circ} \mathrm{C}$. The $\mathrm{MS}$ is a dual focusing magnetic sector instrument (Autospec Ultra, Waters Corp.), which is tuned to a mass resolution of approximately $6000(\mathrm{~m} / \Delta \mathrm{m})$ at $5 \%$ peak height.

The instrument calibration is based on ppt-level gas standards prepared in our laboratory from pure compounds with a two step dilution method (Aydin et al., 2007). The Autospec instrument is susceptible to occasional step changes in sensitivity of $10-20 \%$. To correct for such changes, we typically add an internal gas standard to each sample containing a deuterated or ${ }^{13} \mathrm{C}$ isotopologue of each analyte. This was not done for CFC-12 since the original intent was to monitor CFC-12 only as a marker for contamination. CFC-12 was calibrated with external standards only. As a result, the reproducibility of the CFC-12 data for ambient air samples of $100 \mathrm{ml} \mathrm{STP}$ is $5 \%( \pm 1 \sigma)$.

\subsection{Firn air analysis (UCI)}

The only firn samples analyzed at UCI were one set of samples collected at the WAIS-D site from two adjacent holes. A different set of WAIS-D flasks collected from the same two holes was analyzed separately at NOAA/ESRL and will be discussed in the following section. Firn air samples are obtained by sequentially drilling to various depths, inserting a plug (a $4 \mathrm{~m}$ long rubber bladder) about $20 \mathrm{~cm}$ above the bottom of the hole, and pumping air from the bottom via a flexible tube inserted through the plug. Previously established procedures were implemented unchanged (Schwander et al., 1993; Bender et al., 1994; Battle et al., 1996). All UCI samples were collected after thorough flushing of two-port, $2 \mathrm{~L}$ glass flasks, which were subsequently pressurized to about $210 \mathrm{kPa}$ and shipped back for laboratory analysis. The measurements were completed 4-5 months after the collection of the samples. 
The firn air samples were analyzed on the same GC-MS instrument that was used for ice core samples. On average, $81 \pm 9 \mathrm{ml}( \pm 1 \sigma)$ STP of air was analyzed from each flask. As is the case for the ice core data, the largest source of uncertainty in UCI CFC-12 data is the instrumental drift, which could not be corrected for due to lack of an internal standard for this compound. The average standard deviation in the replicate runs was $4.5 \%$ of the reported mixing ratio.

\subsection{Firn air analysis (NOAA)}

Firn air was also collected with identical techniques in sets of two-port stainless steel and glass flasks and subsequently analyzed at the NOAA/ESRL labs in Boulder, Colorado. The Siple Dome and SPO'95 flasks were analyzed with gas chromatography coupled with electron capture detection (ECD) (Butler et al., 1999). The SPO'01 and WAIS-D flasks were analyzed on a separate GC-MS system (Montzka et al, 2004). For the ECD analysis of flasks, mean CFC-12 mixing ratios in flask pairs filled in parallel typically differ by $<1.1 \mathrm{ppt}$ $(<0.4 \%$ in $90 \%$ of flask pairs). For flasks analyzed by mass spectrometry mean CFC-12 mixing ratios typically differ by $<2.5 \mathrm{ppt}(<1.3 \%$ in $90 \%$ of the flask pairs). Non-linearity in the ECD response is corrected based on gravimetric standards ranging from 78 to 647 ppt (Butler et al., 1999). GCMS response is observed to be linear during the analyses of gravimetric standards. Zero air samples are regularly run as instrument blanks, which are used for linear interpolation of calibration curves down to $0 \mathrm{ppt}$.

\subsection{Firn air modeling}

Model calculations for all sites were carried out using the UCI firn air model. This is a one dimensional diffusion model with a fixed snow accumulation rate, and a vertically variable diffusivity (Schwander et al., 1988, 1993). The distribution of open porosity with depth is obtained using measured density profiles and a density-open porosity relationship following Schwander (1989) and Schwander et al. (1988), except open porosity is assumed to vanish at the deepest sampling depth for each firn hole. Effective gas diffusion coefficients in the model are variable with depth as they are scaled to change with the open porosity. The parameterization between diffusivity and open porosity is tuned to generate realistic $\mathrm{CO}_{2}$ profiles with known atmospheric histories of this gas (Etheridge et al., 1996; Conway et al., 2004). A detailed description of the tuning procedures and physical parameters used in the UCI firn model is provided by Aydin et al. (2004) and Montzka et al. (2004).

The CFC-12 atmospheric history (ftp://ftp.cmdl.noaa.gov/ hats/firnair/) used in the model runs was constructed from industrial emissions estimates (for 1930-1978) and the southern hemispheric means of the NOAA flask and in-situ measurement programs (for 1978-2008). This atmospheric history is similar to the one tested and confirmed by Butler et
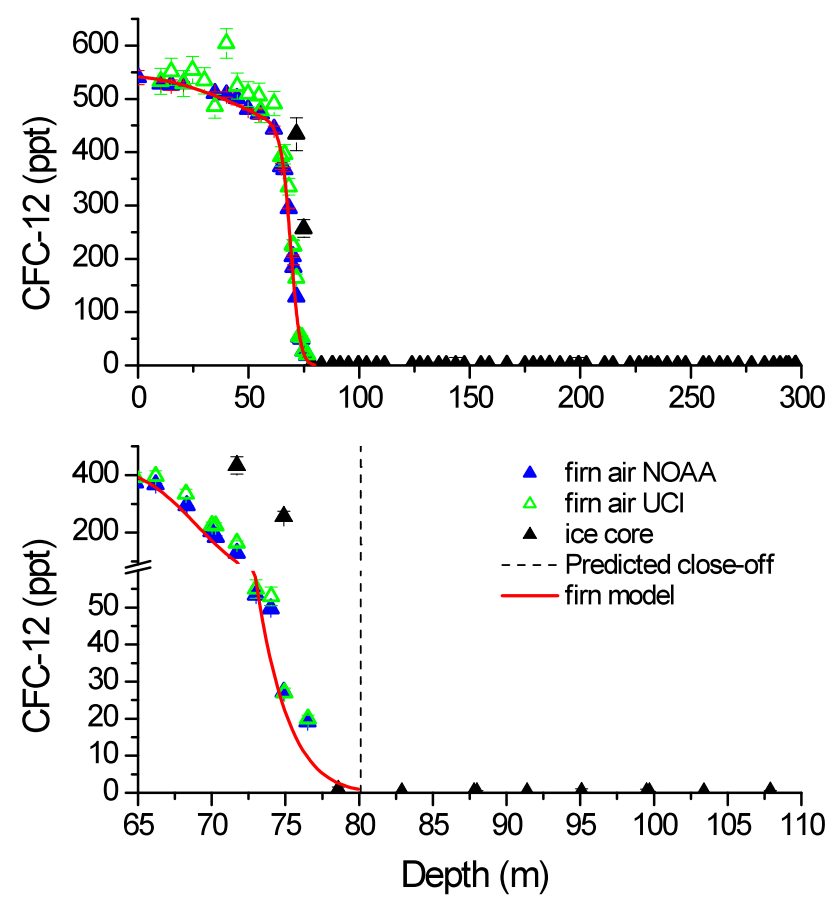

Fig. 1. Both panels - NOAA firn air data from the 2005 campaign (blue triangles) at WAIS-D, UCI firn air data (green triangles) for the same campaign, and UCI ice core data (black triangles) for the ice cores drilled the same year from a neighboring hole. The red line is the CFC-12 profile generated by the firn model. In the lower panel, the scales of $x$ - and $y$-axes are adjusted to focus in on the firn-ice transition. The dashed line represents the full firn close-off depth as estimated by Eq. (1).

al. (1999). It agrees well with the CFC-12 atmospheric history derived from the ALE/GAGE/AGAGE flask network measurements and industry emissions data (Walker et al., 2000).

\section{Results}

\subsection{WAIS-Divide}

Two sets of glass flasks were collected simultaneously during the WAIS-D field campaign for analysis at NOAA and UCI. The NOAA firn air measurements show CFC-12 levels rising steeply from $19 \mathrm{ppt}$ at $76.5 \mathrm{~m}$, to $350-400 \mathrm{ppt}$ at $66 \mathrm{~m}$, followed by a more gradual increase to $532 \mathrm{ppt}$ at the surface (Fig. 1). There is agreement between the NOAA and UCI results, within the estimated analytical uncertainty of the measurements. Most of this uncertainty is attributed to drift in the UCI mass spectrometer response, as noted above. The model generated profile agrees well with the data, indicating that the CFC-12 measurements from WAIS-D firn are consistent with the known atmospheric history of this compound (Fig. 1). 

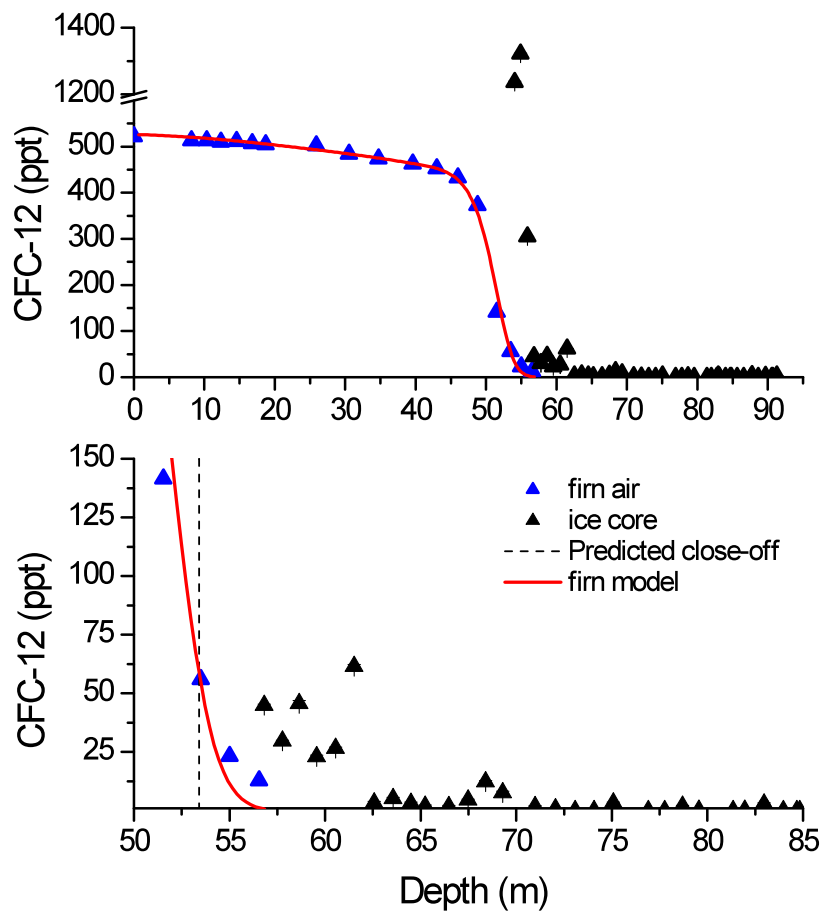

Fig. 2. Both panels - NOAA firn air data from the 1996 campaign (blue triangles) at Siple Dome, and UCI ice core data (black triangles) for Siple Dome C ice core drilled in 1995. The red line is the $\mathrm{CFC}-12$ profile generated by the firn model. In the lower panel, the scales of $\mathrm{x}$ - and $\mathrm{y}$-axes are adjusted to focus in on the firn-ice transition. The dashed line represents the full firn close-off depth as estimated by Eq. (1).

Results from 4 ice samples $(143.6 \mathrm{~m}, 162.6 \mathrm{~m}, 199.3 \mathrm{~m}$, and $232.0 \mathrm{~m}$ ) out of a total of 57 from the WAIS-D 05A core are not included in the analyses because CFC-12 measurements in pre- or post-shred blanks indicated leaks into the extraction chamber. In the rest of the ice core samples, there was no measurable CFC-12 below the maximum firn sampling depth at $76.5 \mathrm{~m}$ (Fig. 1). This horizon will be referred to as the firn sampling threshold depth (FSTD) in the rest of this manuscript. The FSTD marks the point below which flows of air from open pores during sampling becomes negligible. However, as discussed below, it does not mark the completion of the bubble close-off process. The shallowest ice sample below the FSTD at WAIS-D is from $78.6 \mathrm{~m}$ and has a CFC-12 mixing ratio of $0.7 \pm 0.9 \mathrm{ppt}$. Air at this depth has a methane date of 1940 C.E. (Mischler et al., 2009). The ice core mixing ratio of $0.7 \pm 0.9 \mathrm{ppt}$ is consistent with the atmospheric history of CFC-12, which shows a rise from $0 \mathrm{ppt}$ to $1 \mathrm{ppt}$ between 1935 and 1945 (ftp://ftp.cmdl.noaa.gov/hats/firnair/). Samples below that depth contain older air and are not expected to contain CFC12 at detectable levels.
Two ice core samples from above the FSTD contained measurable CFC-12 (257 ppt at $74.9 \mathrm{~m}$, and $434 \mathrm{ppt}$ at $71.7 \mathrm{~m}$ ). These CFC-12 mixing ratios are much higher than those in firn air from similar depths (49 ppt at $74.0 \mathrm{~m}$, and $129 \mathrm{ppt}$ at $71.7 \mathrm{~m}$ ). The air trapped in bubbles should be similar in age, or slightly older, than the firn air at a given depth since firn air can continue to mix with younger air from shallower depths. Indeed, we were unable to recreate CFC-12 mixing ratios measured in ice core air for any plausible combination of diffusivity and bubble formation distribution with depth. The unexpectedly high levels of CFC-12 at depths above the FSTD can only be explained by existence of some amount of modern air in the sample. It is highly unlikely that this is contamination that occurred during extraction or analysis in the laboratory since the observation is limited to samples above the FSTD only. We conclude that an exogenous process (post-coring bubble closure) is needed to account for the observations.

\subsection{Siple Dome}

The FSTD at Siple Dome is $56.5 \mathrm{~m}$ and the CFC-12 mixing ratio of the sample from this depth is $13 \mathrm{ppt}$ (Fig. 2). The Siple Dome firn data are similar to WAIS-D in that the first $10 \mathrm{~m}$ from the bottom is characterized by a steep increase that is followed by a more gradual rise to surface values. This CFC-12 firn profile agrees well with the known CFC-12 atmospheric history in numerical simulations (Fig. 2).

In the SDM-C ice core samples, CFC-12 was undetectable in 19 out of 25 samples from 70-92 m with 6 samples measuring 1-4 ppt. All 9 samples between 62-69 m had measurable CFC-12 with 4 samples measuring higher than 4 ppt and a maximum of $13 \mathrm{ppt}$ at $68.4 \mathrm{~m}$ (Fig. 2). Higher above, CFC12 rises sharply from $25-50 \mathrm{ppt}$ at $62 \mathrm{~m}$ to about $1300 \mathrm{ppt}$ at $54 \mathrm{~m}$. There are a total of nine samples between 54$62 \mathrm{~m}$, three of which are from above the FSTD. The CFC-12 mixing ratio measured in these three samples from $54.1 \mathrm{~m}$, $54.9 \mathrm{~m}$, and $55.9 \mathrm{~m}$ are $1236 \mathrm{ppt}, 1321 \mathrm{ppt}$, and $305 \mathrm{ppt}$, respectively. For the six samples just below the FSTD, CFC-12 averaged $39 \pm 15 \mathrm{ppt}( \pm 1 \sigma)$.

The CFC-12 levels in the SDM-C samples from just above the FSTD at $54.1 \mathrm{~m}, 54.9 \mathrm{~m}$, and $55.9 \mathrm{~m}$ are higher than those observed above the FSTD at WAIS-D. Two out of three of these samples have CFC-12 mixing ratios that are more than twice the atmospheric levels observed during the late 1990's (ftp://ftp.cmdl.noaa.gov/hats/firnair/). Apparently, these ice core samples were exposed to air with anomalously high levels of CFC-12, and that some of this contaminated air was trapped in the samples. SDM-C results differ from WAIS-D data in that the samples from below the FSTD (56-68 m) also display elevated CFC-12 levels. 


\subsection{South Pole}

CFC-12 mixing ratios of 2-4 ppt at the bottom of the SPO firn are considerably lower than those measured at the other two sites (Fig. 3), indicating older gas ages at the bottom of the SPO firn (Table 1; Battle et al., 1996; Butler et al., 1999). Over intermediate and shallow depths, the SPO'01 and SPO'95 profiles differ by several tens of ppt. This difference reflects both the incorporation of the increasing CFC12 burden in the atmosphere between 1995 and 2001 into the SPO firn and its subsequent downward diffusion into the firn as simulated by the model runs (Fig. 3).

The FSTD at SPO is $121 \mathrm{~m}$. No SPRESSO ice core samples above the FSTD were analyzed, however, there is measurable CFC-12 in ice from several meters below the FSTD (Fig. 3). The CFC-12 content of ice increases rapidly from $0.4 \pm 0.3 \mathrm{ppt}$ at $140.2 \mathrm{~m}$ to $257 \pm 1 \mathrm{ppt}$ at $124.6 \mathrm{~m}$. Of the 15 samples between $140.2 \mathrm{~m}$ and $124.6 \mathrm{~m}$, there are detectable levels of CFC-12 in all but three. There is also evidence of elevated CFC-12 in a few of the deeper samples between $140 \mathrm{~m}$ and $160 \mathrm{~m}$. The only other section of this core where CFC12 was detectable is below $260 \mathrm{~m}$ where the ice core quality was poor, suggesting perhaps some post-coring entrapment of CFC-12 in the fractures of the brittle ice. It is also for this reason that gases were analyzed in only three samples between $280 \mathrm{~m}$ and $300 \mathrm{~m}$.

\section{Upper limits on the extent of the post-coring entrapment of modern air}

The elevated CFC-12 in some of the ice core samples suggests that a modern air component is incorporated into the ice cores after drilling. The fraction of the modern air entrapped in these samples can be estimated only if the mixing ratio of this component is known. One can assume that the mixing ratio of this component was the same as the surface air mixing ratio at the time of drilling and during subsequent storage. However, two of the samples from Siple Dome have CFC-12 levels more than twice that of peak levels in the atmosphere, indicating that the modern component in these samples is enriched in CFC-12 compared to surface air. Siple Dome core has the earliest collection date among the three cores analyzed in this study, dating back to 1995 when the ban on use and production of CFC-12 first took effect under Montreal Protocol (Clerbaux et al., 2006). The enrichment might have occurred during storage. Freezer systems that use CFC-12 as a refrigerant and the insulating foams used in ice core storage boxes and freezer containers are two potential sources of CFC-12 enriched air. In the remainder of this section, the fraction of the modern air entrapped in CFC-12 containing samples from WAIS-D and SPRESSO is calculated using ambient CFC-12 levels as one of the mixing end members. It cannot be ruled out that the entrapped air was CFC-12 enriched, as in the case of Siple Dome, which implies that the

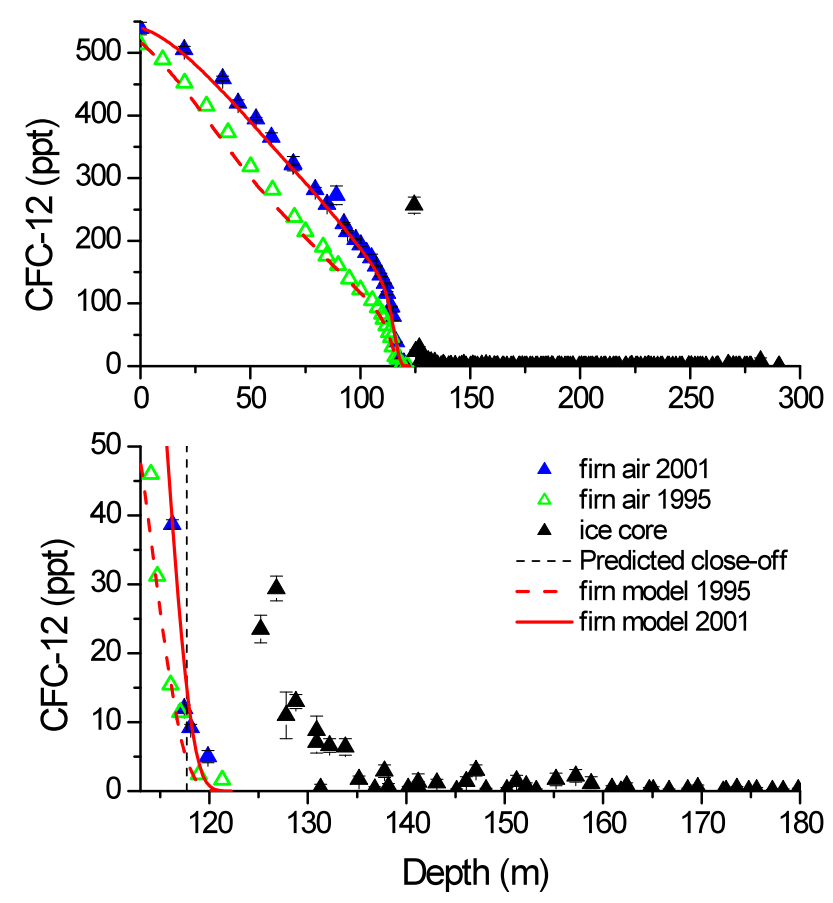

Fig. 3. Both panels - NOAA firn air data from the 1995 (green triangles) and the 2001 (blue triangles) firn campaigns at South Pole, and UCI ice core data (black triangles) from the SPRESSO site. The solid and dashed red lines are the CFC-12 profiles generated by the firn model for the 1995 and the 2001 firn samplings, respectively. In the lower panel, the scales of $\mathrm{x}$ - and $\mathrm{y}$-axes are adjusted to focus in on the firn-ice transition. The dashed line represents the full firn close-off depth as estimated by Eq. (1).

results presented below set only an upper limit for the inferred contributions.

We made two assumptions to calculate the modern air fraction in WAIS-D samples from $71.7 \mathrm{~m}$ and $74.9 \mathrm{~m}$ : 1) CFC12 level of the modern component is $540 \mathrm{ppt}$ (ftp://ftp.cmdl. noaa.gov/hats/firnair/), and 2) the pores that closed in situ contain the same CFC-12 level as firn air at the same depth. Under these assumptions, postdepositional entrapment contributes $74 \%$ of the total closed porosity at $71.7 \mathrm{~m}$, and $45 \%$ at $74.9 \mathrm{~m}$. The total closed porosity in these ice core samples can be estimated from the amount of gas recovered during extraction of the sample for analysis. In addition to the closed porosity, the amount of gas released during extraction of ice core samples is a function of the sample weight and the extraction efficiency. To account for the differences in sample weight, which was not measured, we only looked at samples of a uniform shape that were cut to $0.1 \mathrm{~m}$ in length, similar to the shallowest two pieces. However, during the sample preparation stage the outer surfaces of the samples are shaved off just prior to loading. This is done by hand, using a scalpel, and randomly alters the weight of samples in addition to other irregularities in shape that will introduce variability to the sample weights. We found a small but significant 
negative trend (c.i. $=0.95$ ) in gas yield (moles of air per sample) with depth, probably due to a correlating decrease in bubble size and a concomitant drop in extraction efficiency. Extrapolating this trend predicts that samples between 70 $80 \mathrm{~m}$ depth should yield $7.2 \pm 1.8 \times 10^{-3} \mathrm{~mol}(\mathrm{c} . \mathrm{i} .=0.95)$ of air, with the uncertainty largely reflecting the random variability in extraction efficiency. The actual amounts of air recovered during the extraction of the $71.7 \mathrm{~m}$ and $74.9 \mathrm{~m}$ samples are $4.8 \times 10^{-3} \mathrm{~mol}$ and $6.2 \times 10^{-3} \mathrm{~mol}$. This result suggests that, at the time of analysis, there was still open porosity remaining in the shallower sample, but that the porosity in the $74.9 \mathrm{~m}$ sample was essentially closed.

We calculated the fraction of closed porosity that closed after collection for the SPRESSO samples, using a surface air value of $541 \mathrm{ppt}$ for 2002 (ftp://ftp.cmdl.noaa.gov/hats/ firnair/) but with the assumption that the CFC-12 mixing ratio would be zero if there was no modern air component. The shallowest sample from $124.6 \mathrm{~m}$ contains $257.1 \mathrm{ppt}$ of CFC12 , implying that $48 \%$ of the closed porosity closed after collection. The fraction quickly drops to about $5 \%$ at $125.2 \mathrm{~m}$ and $126.8 \mathrm{~m}$, stays at $1-2 \%$ in $127-134 \mathrm{~m}$ range, and less than that for samples below with the exception of one sample from $282.1 \mathrm{~m}$ at $2 \%$. Based on the amounts of air recovered during extraction of SPRESSO samples, there is no indication that any of the samples still had open porosity at the time of the analysis.

\section{CFC-12 data and empirical estimates of full close-off depth}

Schwander et al. (1993) measured profiles of density and closed porosity at Summit, Greenland and proposed an empirical equation that parameterizes closed porosity with density. Severinghaus and Battle (2006) modified this model and described the closed porosity as a linear function of ice density below the density horizon of $815 \mathrm{~kg} / \mathrm{m}^{3}$ :

$$
\begin{aligned}
& S_{c}=S \times \exp [75 \times(\rho / 837.3-1)] \rho<815 \mathrm{~kg} / \mathrm{m}^{3} \\
& S_{c}=0.0016105 \times \rho-1.297 \rho \geq 815 \mathrm{~kg} / \mathrm{m}^{3}
\end{aligned}
$$

In Eq. (1), $S, S_{c}$, and $\rho$ represent total porosity, closed porosity, and ice density. Open porosity is calculated from the difference between total porosity (obtained from the density) and the closed porosity.

Based on the ice density measurements from Siple Dome, WAIS-D, and SPO'01 (Fig. 4), this equation predicts full close-off at $53.4 \mathrm{~m}, 80.1 \mathrm{~m}$, and $117.7 \mathrm{~m}$ for these three sites, respectively. These depths are shallower than the FSTD's by $3 \mathrm{~m}$ at Siple Dome and $6 \mathrm{~m}$ at South Pole. We expect the true depth of full close-off to be somewhat deeper than the FSTD, as firn air sampling requires a substantial flow of air through a network of connected pores. The existence of elevated CFC12 values below the FSTD at both Siple Dome and South Pole confirms the presence of open porosity below the FSTD and highlights the mismatch between predicted and observed

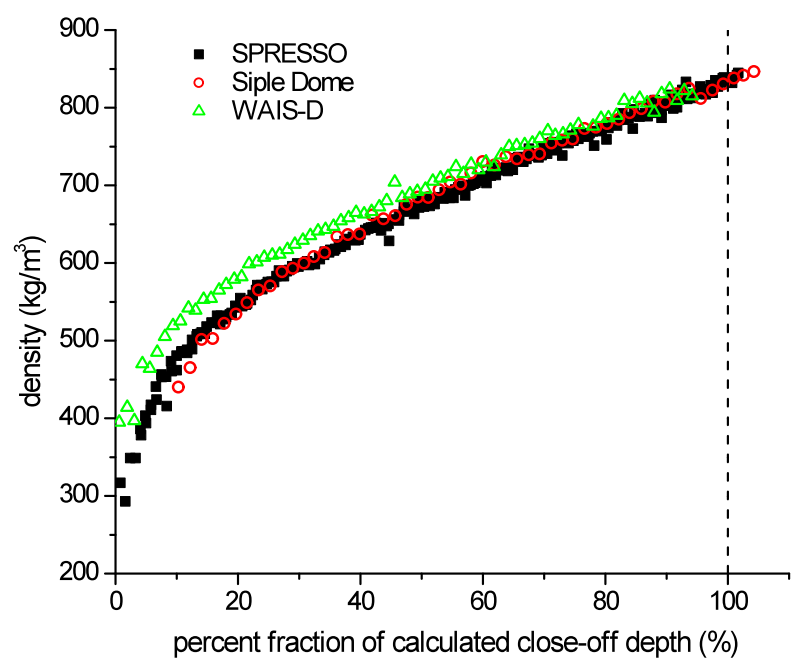

Fig. 4. Ice density for SPRESSO (black squares), Siple Dome (red circles), and WAIS-D (green triangles) cores. The x-axis is a normalized depth scale calculated by dividing the depth of density measurements by the firn close-off depth calculated from Eq. (1) (surface at $0 \%$ ). The dashed line indicates full close-off as predicted by this equation. The density data extend to the actual depth, at which the deepest firn sample at each individual site was collected.

full close-off depths at these sites. In contrast, the equation predicts the full close-off to be approximately $4 \mathrm{~m}$ below the FSTD at WAIS-D and there are no elevated CFC-12 values below the predicted full close-off. Thus, we conclude that Eq. (1) is roughly consistent with observations (or perhaps even too deep) at this site.

The fact that Eq. (1) fails badly at two sites while working reasonably well at a third suggests that there probably is no universal relationship between porosity and density that is applicable to sites with a range of mean annual temperatures and accumulation rates. It may well be significant that the densification at WAIS-D also differs from the other two study sites. Density at WAIS-D remains consistently higher than Siple Dome and South Pole through the top $70 \%$ of the firn column (Fig. 4).

It has been suggested that density is not a good indicator of ice permeability, which correlates with open porosity, and that permeability is strongly affected by variations in the physical properties of ice (Albert et al., 2000). At sites with slower accumulation rates, even small variations in the accumulation rate can cause differences in the physical properties of ice and impact the permeability (Courville et al., 2007). The snow accumulation at South Pole is subject to spatial and temporal variations even in the absence of significant climatic changes (van der Veen et al., 1999). It may be that the existence of open porosity below the FSTD at lower accumulation rate sites is at least partly a consequence of depth-dependent variations in ice microstructure caused by changes in accumulation rates over inter-annual and interdecadal times scales. 


\section{Conclusions}

Through an examination of firn air and ice core samples, this study presents evidence from three Antarctic sites for the presence of unexpectedly high CFC-12 levels in some ice core samples near the firn-ice transition region. It is highly unlikely that the observations can be attributed to in situ production or analysis artifacts because CFC-12 levels are undetectable in deeper ice, and firn air profiles are consistent with the known history of industrial production of this compound. At Siple Dome, exposure to a highly enriched source of CFC-12 is required to explain the elevated levels. This may also be the case at WAIS-D and South Pole, but it is not required to explain the observations. The most likely explanation for the observations is the entrapment of modern air after the collection of the ice cores, likely due to closure of open pores that exist at the time of recovery.

Most ice coring sites are at high elevation and the cores are subjected to higher barometric pressures than the in situ equilibrium pressure of the air inside the open pores after being transported off the drilling site. We hypothesize that modern air rich in CFC-12 can get incorporated into the core by moving through the existing channels, driven by gradients in $\Delta P$ induced flow or via turbulent diffusion. The open pores must later close, possibly due to successional sublimation and recrystallization. The laboratory analysis of SPRESSO, Siple Dome, and WAIS-D samples were completed roughly within $3 \mathrm{y}, 7 \mathrm{y}$, and $2 \mathrm{y}$ after their drilling, apparently providing sufficient time for this process to occur.

A notable result from this study is that at the two sites with slower accumulation rates (Siple Dome and South Pole), open porosity seems to persist well below the depth at which firn air can no longer be extracted from a borehole. The accuracy of empirical relationships between closed porosity and density seem to be site specific and appear to be less reliable at sites with lower accumulation rates. At all three study sites, the extent of post-coring entrapment appears to increase rapidly once above the FSTD. Air extracted from ice core samples collected from above the FSTD should be assumed to contain some fraction of modern air at most drilling sites. One notable exception could be sites with very high accumulation rates. Etheridge et al. $(1996,1998)$ and MacFarling Meure et al. (2006) compared $\mathrm{CO}_{2}, \mathrm{CH}_{4}$, and $\mathrm{N}_{2} \mathrm{O}$ measurements in air from the deepest $5 \mathrm{~m}$ of the firn with measurements in ice core bubbles at Law Dome, Antarctica and did not observe any discrepancies attributable to the processes we discuss here. The accumulation rate at Law Dome was about 6 times higher than the WAIS-D site at $1.2 \mathrm{~m} / \mathrm{y}$ (ice equivalent), consistent with our hypothesis that the alteration of ice core trace compositions due to post-coring entrapment of modern air may be inversely related to accumulation rate. It should also be noted that the very fast accumulation at Law Dome enables selective analysis of samples from denser winter layers, in which the bubble close-off occurs at shallower depths than the summer layers (Etheridge et al., 1992, 1996; Martinerie et al., 1992). The sample requirements of our analysis and the accumulation rates at the study sites preclude such selective sampling.

The results of this study have no implications on the ice core gas records derived from the analysis of deep ice core samples, or the majority of the shallow ice cores samples that do not contain any open porosity at the time of collection. We detected no CFC-12 in deeper sections of the cores at any of the study sites, indicating that anomalous gas measurements close to the firn-ice transition do not categorically invalidate measurements from an entire ice core. However, analyses of shallow ice core samples that may contain open pores at the time of collection should be interpreted with caution. Sowers et al. (1989) saw evidence that during storage, the elemental composition of $\mathrm{N}_{2}, \mathrm{O}_{2}$, and $\mathrm{Ar}$ in shallow ice cores may change. Our data show that post-coring entrapment can occur, implying that at sites with low to medium accumulation rates, it may not be possible to establish continuity between trace gas measurements in firn air and shallow ice cores. Further studies are needed to better quantify the magnitude of the entrapment. The anthropogenically produced CFC, HCFC, and HFC compounds may be ideal for such studies because they are nonreactive and have well defined atmospheric histories.

Acknowledgements. This work was supported by National Science Foundation's Office of Polar Programs (OPP-0440602, OPP-0338359, OPP-0636953, and OPP-0440509). We thank Todd Sowers and Mark Drier for the density data from WAIS-D, Andy Clarke and Jay Kyne for the density data from SPO'01, and Greg Lamorey for the density data from Siple Dome. We thank Mary Albert for discussions during the preparation of the manuscript. We also thank ICDS and drillers for their assistance in recovery of ice cores, as well as Kent Anderson for the SPRESSO core, Siple Dome SCO for SDM-C core.

Edited by: T. Röckmann

\section{References}

Albert, M. R., Shultz, E. F., and Perron, F. E.: Snow and firn permeability at Siple Dome, Antarctica, Ann. Glaciol., 31(1), 353-356, 2000.

Anklin, M., Schwander, J., Stauffer, B., Tschumi, J., and Fuchs, A.: $\mathrm{CO}_{2}$ record between 40 and 8 kyr B.P. from the Greenland Ice Core Project ice core, J. Geophys. Res., 102, 26539-26545, 1997.

Aydin, M., Williams, M. B., Tatum, C., and Saltzman, E. S.: Carbonyl sulfide in air extracted from a South Pole ice core: a 2000 year record, Atmos. Chem. Phys., 8, 7533-7542, doi:10.5194/acp-8-7533-2008, 2008.

Aydin, M., Williams, M. B., and Saltzman, E. S.: Feasibility of reconstructing paleoatmospheric records of selected alkanes, methyl halides, and sulfur gases from Greenland ice cores, J. Geophys. Res., 112, D07312, doi:10.1029/2006JD008027, 2007. Aydin, M., Saltzman, E. S., De Bruyn, W. J., Montzka, S. A., Butler, J. H., and Battle, M.: Atmospheric variability of methyl chloride 
during the last 300 years from an Antarctic ice core and firn air, Geophys. Res. Lett., 31, L02109, doi:10.1029/2003GL018750, 2004.

Aydin, M., DeBruyn, W. J., and Saltzman, E. S.: Preindustrial atmospheric carbonyl sulfide (OCS) from an Antarctic ice core, Geophys. Res. Lett., 2, 1359, doi:10.1029/2002GL014796, 2002.

Battle, M., Bender, M. L., Sowers, T., Tans, P. P., Butler, J. H., Elkins, J. W., Ellis, J. T., Conway, T., Zhang, N., Lang, P., and Clarke, A. D.: Atmospheric gas concentrations over the past century measured in air from firn at the South Pole, Nature, 383, 231-235, 1996.

Bender, M. L.: Orbital tuning chronology for the Vostok climate record supported by trapped gas composition, Earth Planet. Sci. Lett., 204, 275-289, 2002.

Bender, M. L., Sowers, T., and Lipenkov, V.: On the concentrations of $\mathrm{O}_{2}, \mathrm{~N}_{2}$, and $\mathrm{Ar}$ in trapped gases from ice cores, J. Geophys. Res., 100, 18651-18660, 1995.

Bender, M. L., Sowers, T., Barnola, J.-M., and Chappellaz, J.: Changes in the $\mathrm{O} 2 / \mathrm{N} 2$ ratio of the atmosphere during recent decades reflected in the composition of air in the firn at Vostok station, Antarctica, Geophys. Res. Lett., 21(3), 189-192, 1994.

Brook, E. J., Sowers, T., and Orchardo, J.: Rapid variations in atmospheric methane concentration during the last 110,000 years, Science, 273, 1087-1091, 1996.

Butler, J. H., Battle, M., Bender, M. L., Montzka, S. A., Clarke, A. D., Saltzman, E. S., Sucher, C. M., Severinghaus, J. P., and Elkins, J. W.: A record of atmospheric halocarbons during the twentieth century from polar firn air, Nature, 399, 749-755, 1999.

Clerbaux, E., Cunnold, D. M., Anderson, J., Engel, A., Fraser, P. J., Mahieu, E., Manning, A., Miller, J., Montzka, S. A., Nassar, R., Prinn, R., Reimann, S., Rinsland, C. P., Simmonds, P., Verdonik, D., Weiss, R., Wuebbles, D., and Yokouchi, Y.: Longlived compounds, in Scientific Assessment of Ozone Depletion: 2006, Global Ozone Research and Monitoring Project - Report No. 50, edited by: W. M. Organization, World Meteorological Organization, Geneva, 2006.

Conway, T. J., Andrews, A. E., Bruwhiler, L., Crotwell, A., Dlugokencky, E. J., Hahn, M. P., Hirsch, A. I., Kitzis, D. R., Lang, P. M., Masarie, K. A., Michalak, A. M., Miller, J. B., Novelli, P. C. Peters, Tans, P. P., Thoning, K. W. Vaughn, B. H., and Zhao, C.: Carbon cycle greenhouse gases, in Climate Monitoring and Diagnostics Laboratory Summary Report No. 27 2002-2003, Chapter. 2, edited by: Schnell, R., Buggle, D. A.-M., and Rosson, R., Natl. Oceanic and Atmos. Admin., Boulder, Colo., 32-57, 2004.

Courville, Z. R., Albert, M. R., Fahnestock, M. A., Cathles IV, L. M., and Shuman, C. A.: Impacts of an accumulation hiatus on the physical properties of firn at a low-accumulation polar site, J. Geophys. Res., 112, F02030, doi:10.1029/2005JF000429, 2007.

Craig, H., Horibe, Y., and Sowers, T.: Gravitational separation of gases and isotopes in polar ice caps, Science, 242, 1675-1678, 1988.

Delmas, R. J.: A natural artifact in Greenland ice core $\mathrm{CO}_{2}$ measurements, Tellus, 45B, 391-396, 1993.

Etheridge, D. M., Steele, L. P., Francey, R. J., and Langenfelds, R. L.: Atmospheric methane between 1000 A.D. and present: Evidence of anthropogenic emissions and climatic variability, J. Geophys. Res., 103(D13), 15979-15993, 1998.

Etheridge, D. M., Steele, L. P., Langenfelds, R. L., Francey, R. J.,
Barnola, J.-M., and Morgan, V. I.: Natural and anthropogenic changes in atmospheric $\mathrm{CO}_{2}$ over the last 1000 years from air in Antarctic ice and firn, J. Geophys. Res., 101(D2), 4115-4128, 1996.

Etheridge, D. M., Pearman, G. I., and Fraser, P. J.: Changes in tropospheric methane between 1841 and 1978 from a high accumulation-rate Antarctic ice core, Tellus, 44B, 282-294, 1992.

Haan, D. and Raynaud, D.: Ice core record of CO variations during the last two millennia: atmospheric implications and chemical interactions within the Greenland ice, Tellus, 50B, 253-262, 1998.

Ikeda-Fukazawaa, T., Fukumizu, K., Kawamura, K., Aoki, S., Nakazawa, T., and Hondoh, T.: Effects of molecular diffusion on trapped gas composition in polar ice cores, Earth Planet. Sci. Lett., 229, 183-192, 2005.

Lüthi, D., Le Floch, M., Bereiter, B., Blunier, T., Barnola, J.-M., Siegenthaler, U., Raynaud, D., Jouzel, J., Fischer, H., Kawamura, K., and Stocker, T. F.: High-resolution carbon dioxide concentration record 650,000-800,000 years before present, Nature, 453, 379-382, doi:10.1038/nature06949, 2008.

MacFarling Meure, C., Etheridge, D. M., Trudinger, C., Steele, P., Langenfelds, R., van Ommen, T., Smith, A., and Elkins, J.: Law Dome $\mathrm{CO}_{2}, \mathrm{CH}_{4}$ and $\mathrm{N}_{2} \mathrm{O}$ ice core records extended to 2000 years BP, Geophys. Res. Lett., 33, L14810, doi:10.1029/2006GL026152, 2006.

Martinerie, P., Raynaud, D., Etheridge, D. M., Barnola, J.-M., and Mazaudier, D.: Physical and climatic parameters which influence the air content in polar ice, Earth Planet. Sci. Lett., 112, 1-13, 1992.

Mischler, J. A., Sowers, T. A., Alley, R. B., Battle, M. O., McConnell, J. R., Mitchell, L., Popp, T., Sofen, E., and Spencer, M. K.: Carbon and hydrogen isotopic composition of methane over the last 1000 years, Global BioGeoChem. Cy., 23, GB4024, doi:10.1029/2009GB003460, 2009.

Montzka, S. A., Aydin, M., Battle, M., Butler, J. H., Saltzman, E. S., Hall, B. D., Clarke, A. D., Mondeel, D., and Elkins, J. W.: A 350-year atmospheric history for carbonyl sulfide inferred from Antarctic firn air and air trapped in ice, J. Geophys. Res., 109, D22302, doi:10.1029/2004JD004686, 2004.

Petit, J. R., Jouzel, J., Raynaud, D., Barkov, N. I., Barnola, J.M., Basile, I., Bender, M., Chappellaz, J., Davis, M., Delaygue, G., Delmotte, M., Kotlyakov, V. M., Legrand, M., Lipenkov, V. Y., Lorius, C., Pepin, L., Ritz, C., Saltzman, E. S., and Stievenard, M.: Climate and atmospheric history of the past 420,00 years from the Vostok ice core, Antarctica, Nature, 399, 426436, 1999.

Saito, T., Yokouchi, Y., Aoki, S., Nakazawa, T., Fujii, Y., and Watanabe, O.: Ice-core record of methyl chloride over the last glacial-Holocene climate change, Geophys. Res. Lett., 34, L03801, doi:10.1029/2006GL028090, 2007.

Saltzman, E. S., Aydin, M., Tatum, C., and Williams, M. B.: 2,000-year record of atmospheric methyl bromide from a South Pole ice core, J. Geophys. Res., 113, D05304, doi:10.1029/2007JD008919, 2008.

Schwander, J., Barnola, J. -M., Andrie, C., Leuenberger, M., Ludin, A., Raynaud, D., and Stauffer, B.: The age of the air in the firn and ice at Summit, Greenland, J. Geophys. Res., 98, 2831-2838, 1993. 
Schwander, J.: The transformation of snow to ice and the occlusion of gases, The Environmental Record in Glaciers and Ice Sheets, edited by: Oeschger, H. and Langway, C. C., Wiley, New York, 53-67, 1989.

Schwander, J., Stauffer, B., and Sigg, A.: Air mixing in firn and the age of the air at pore close-off, Ann. Glaciol., 10, 141-145, 1988.

Severinghaus, J. P. and Battle, M. O.: Fractionation of gases in polar ice during bubble close-off: New constraints from firn air Ne, $\mathrm{Kr}$ and Xe observations, Earth Planet. Sci. Lett., 244, 474-500, 2006.

Severinghaus, J. P., Grachev, A., and Battle, M.: Thermal fractionation of air in polar firn by seasonal temperature gradients, Geochem. Geophys. Geosys., 2, 2000GC000146 ISSN: 15252027, 2001.

Sowers, T., Alley, R. B., and Jubenville, J.: Ice core records of atmospheric $\mathrm{N}_{2} \mathrm{O}$ covering the last 106,000 Years, Science, 301, 945-948, 2003.

Sowers, T., Bender, M. L., and Raynaud, D.: Elemental and isotopic composition of occluded $\mathrm{O}_{2}$ and $\mathrm{N}_{2}$ in polar ice, J. Geophys. Res., 94, 5137-5150, 1989.

Sturges, W. T., McIntyre, H. P., Penkett, S. A., Chappellaz, J. A., Barnola, J.-M., Mulvaney, R., Atlas, E., and Stroud, V.: Methyl bromide, other brominated methanes and methyl iodide in polar firn air, J. Geophys. Res., 106, 1595-1606, 2001a.

Sturges, W. T., Penkett, S. A., Barnola, J.-M., Chappellaz, J., Atlas, E., and Stroud, V.: A long-term record of carbonyl sulfide (COS) in two hemispheres from firn air measurements, Geophys. Res. Lett., 28, 4095-4098, 2001b.
Sturrock, G. A., Etheridge, D. M., Trudinger, C. M., and Fraser, P. J.: Atmospheric histories of halocarbons from analysis of Antarctic firn air: Major Montreal Protocol species, J. Geophys. Res., 107(D24), 4765, doi:10.1029/2002JD002548, 2002.

Trudinger, C. M., Etheridge, D. M., Sturrock, G. A., Fraser, P. J., Krummel, P. B., and McCulloch, A.: Atmospheric histories of halocarbons from analysis of Antarctic firn air: Methyl bromide, methyl chloride, chloroform, and dichloromethane, J. Geophys. Res., 109(D22), D22310, doi:10.1029/2004JD004932, 2004.

Van der Veen, C. J., Mosley-Thompson, E., Gow, A. J., and Mark, B. G.: Accumulation at South Pole: Comparison of two 900-year records, J. Geophys. Res., 104(D24), 31067-31076, 1999.

Walker, S. J., Weiss, R. F., and Salameh, P. K.: Reconstructed histories of the annual mean atmospheric mole fractions for the halocarbons CFC-11, CFC-12, CFC-113, and carbon tetrachloride, J. Geophys. Res., 105, 14285-14296, 2000.

Weis, R. F., Bullister, J. L., Gammon, R. H., and Warner, M. J.: Atmospheric chlorofluoromethanes in the deep equatorial Atlantic, Nature, 314, 608-610, 1985.

Williams, M. B., Aydin, M., Tatum, C., and Saltzman, E. S.: A 2000 year atmospheric history of methyl chloride from a South Pole ice core: Evidence for climate-controlled variability, Geophys. Res. Lett., 34, L07811, doi:10.1029/2006GL029142, 2007. 